J. Clin. Chem. Clin. Biochem.

Vol. 25, 1987, pp. 525-540

(C) 1987 Walter de Gruyter \& Co. Berlin - New York

\title{
Enzyme Release
}

\author{
By Ellen Schmidt and F. W. Schmidt
}

Abt. Gastroenterologie und Hepatologie im Zentrum Innere Medizin und Dermatologie, Medizinische Hochschule Hannover, Hannover, FRG

(Received May 13, 1987)

Summary: Enzyme release was studied in various tissues in intact animals or by means of tissue slices, organ perfusion or isolated and cultured cells. The factors that determine the extent and the time course of the leakage were studied extensively with several liver enzymes. It was found that the molecular properties of the enzymes, their topology within the organ, their intracellular localișation, their inducibility on the one hand, the nutritional and energetic state of the organ, and the respective protein turnover on the other, and finally, the type of the organ lesion all contribute to the different release patterns, which are known from experimental studies, and which are utilized for the diagnosis of diseases.

While these preconditions of enzyme release are fairly well understood, the nature of the membrane alterations and the mechanisms of detachment and transport of the enzyme proteins are less clear. Different models have been proposed, which may not exclude each other. Alterations of the cytoskeleton and the lipid composition of the plasma membranes are closely linked to ion imbalance, which is, in turn, dependent on the energy state of the individual cellular compartments.

\section{Introduction}

Our interest in the phenomenon of cell enzyme release arose soon after we had begun in 1956 to determine enzyme activities in liver biopsies and sera of our patients with liver diseases. The inconsistency between the prevailing doctrine that the cell enzymes in plasma would originate from cell necrosis, and our own experience, shown in figure 1 (1 a), namely that the modifications of the enzyme activities in serum reflect neither directly nor reciprocally the enzyme activities and their respective changes in the liver, induced us to reconsider ( 1 b) and to actively investigate the problem $(2-5)$.

For the purposes of studying enzyme release into plasma without the effects of distribution and elimination $(6,7)$, patients and whole experimental animals were too complicated as experimental systems. Simpler systems were therefore designed, from perfused organs to purely synthetic membranes (tab. 1). The more artificial the systems were, the more susceptible they became to slight variations in methodology, and this may be one reason why different answers are frequently given in the literature to the apparently simple questions:

1. Why do cells lose their enzymes, which they need, and which have no extracellular functions? Is the conservation of the enzyme equipment of cells only a question of energy?

2. What modifies the extent of enzyme losses, so that various, sometimes highly characteristic enzyme patterns appear in plasma, which are different from the enzyme patterns of the organs of origin?

3. How do cellular enzymes pass into the extracellular space?

Which structures and processes are involved actively or passively?

The attempt to answer these questions will start as far as possible - from own investigations, according to the nascent tradition of the Szász Lecture. 

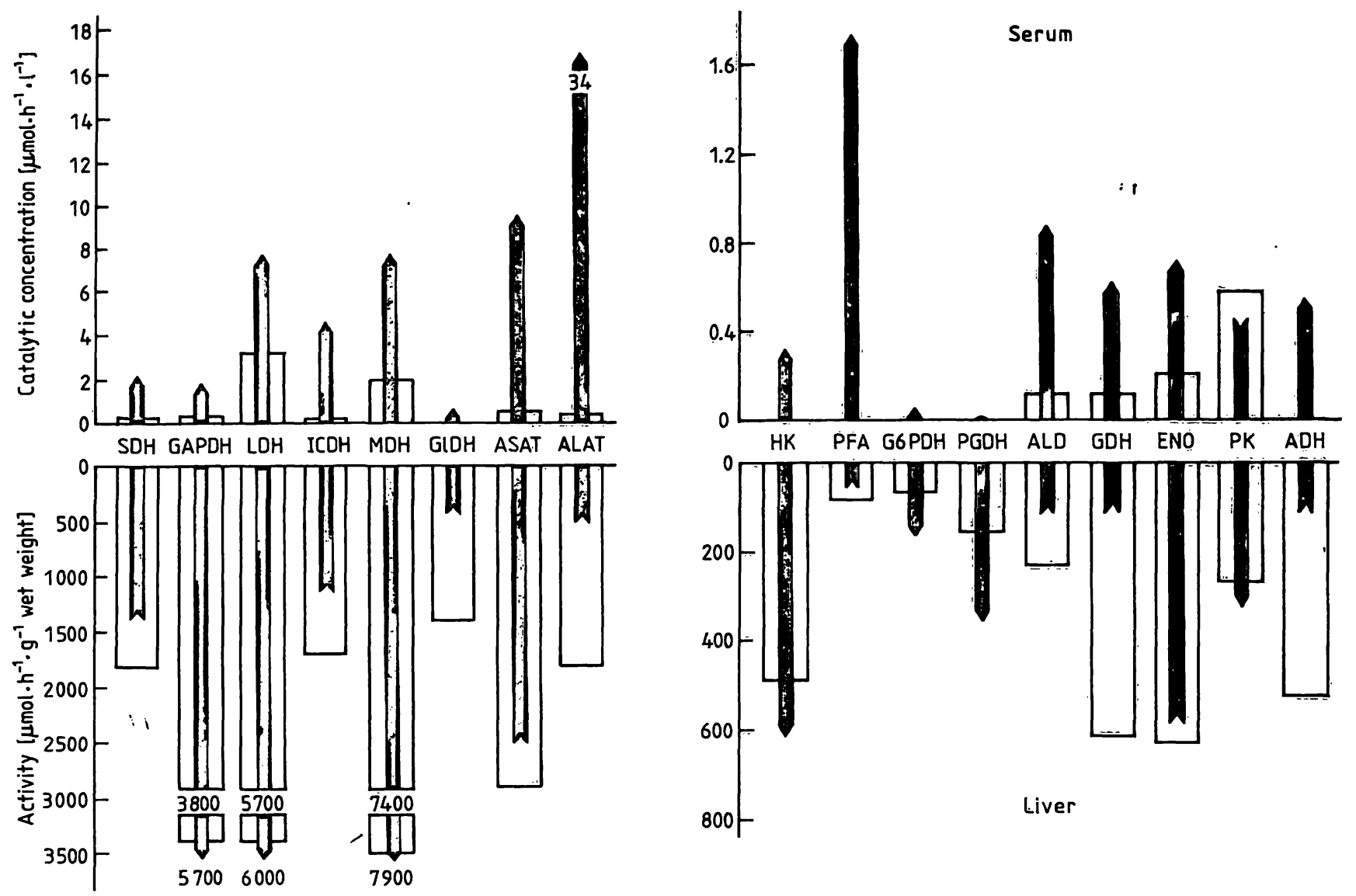

Fig. 1. Enzyme activities in normal human liver and serum (־) and in human liver and serum in acute viral hepatitis ( Because of limited space the enzymes were abbreviated as follows:

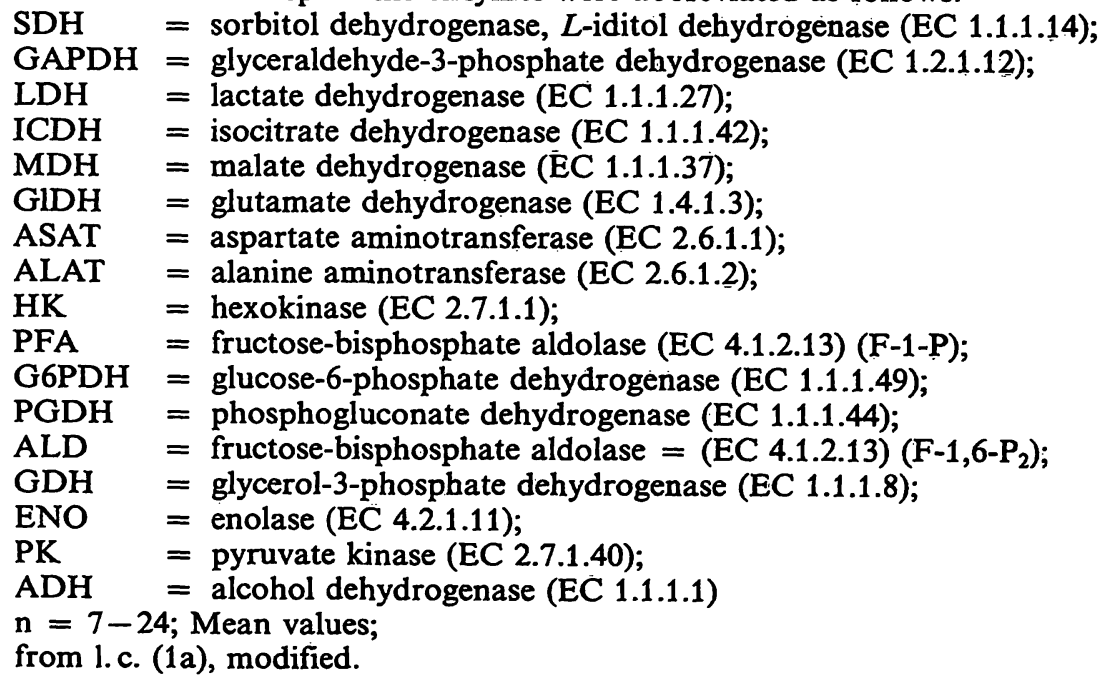

Tab. 1. Systems used in the study of enzyme release.

1. Patients or healthy volunteers

2. Animals, plants, microorganisms

3. Perfused organs

4. Isolated organs or tissue slices

5. Isolated or cultured cells

6. Isolated cell organelles

7. Artificial membranes or vesicles
Various models for the study of enzyme release have been designed on the basis of the respective concepts of cell metabolism, as well in analogy with clinical problems (tab. 2). Thus the investigation of the effects of anoxia have likewise deepened the understanding of myocardial infarction, shock and other states of circulatory failure and have led to new general insights into enzyme release. 
Tab. 2. Models used in the study of enzyme release.

1. Modification of oxygen supply
a) Hypoxia and anoxia
b) Low-flow and ischaemia
c) "The oxygen paradox"

2. Modification of substrate supply
a) Fasting
b) Carbohydrate depletion
c) Protein imbalance

3. Modification of intracellular metabolism
a) Inhibition of glycolysis
b) Inhibition of oxidation
c) Uncoupling of oxidative phosphorylation
d) Inhibition of protein synthesis
e) Enzyme induction

4. Modification of cellular structures
a) Detergent action
b) Impairment of the cytoskeleton
c) Lipid peroxidation
d) Electrolyte imbalance

\section{Modification of oxygen supply}

Figure 2 shows experiments with the isolated haemoglobin-free perfused rat liver $(5,7,8)$. The effects of three different forms of oxygen deprivation on enzyme release are compared with the course of normoxic liver perfusion at $23^{\circ} \mathrm{C}$ (9). As examples, the activities of cytosolic, periportally prevailing alanine aminotransferase, of cytosolic as well as mitochondrial, evenly distributed aspartate aminotransferase, and of purely mitochondrial, perivenously predominant glutamate dehydrogenase are shown in the perfusion medium. As metabolic reference data the oxygen consumption of the liver and the lactate/pyruvate ratio in the medium are given.

Among the curves in figure 2 the temperature-induced relative hypoxia $(\mathrm{H})$ is conspicuous. Although oxygen consumption at $37^{\circ} \mathrm{C}$ is more than twice than at $23^{\circ} \mathrm{C}$, it is insufficient to meet the bigher requirements of the accelerated metabolism (9). After the first hour, the lactate/pyruvate ratio increases steadily and simultaneously with the elevation of aspartate aminotransferase, before the increased release of alanine aminotransferase and after the early leakage of glutamate dehydrogenase. The temporal order is due to the intralobular distribution of the three enzymes and the mainly perivenous site of action of the hypoxic cell damage.

This deduction is supported by the reactions of the three enzymes during and after the one-hour anoxia in the course of the perfusion (A): Only glutamate dehydrogenase shows an immediate, higher release rate, while the aspartate aminotransferase release rate is increased only after re-oxygenation, when oxygen consumption and the lactate/pyruvate ratio have already returned to the initial values. Finally, the slope of alanine aminotransferase elevation does not differ significantly from that of the controls (C).

In the third example, hypothermic perfusion after 20 minutes of warm ischaemia (I), the first activities of the cytosolic enzymes are elevated, for obvious reasons. So is the initial oxygen consumption, which brings the lactate/pyruvate ratio promptly to control levels, and which stays in the control range after the first hour. The further slope of the release rates of the enzymes is then only negligibly steeper than in controls.

The higher sensitivity of the totally or partially cytosolic enzymes, compared with the mitochondrial ones, can be easily recognized from the different scales, which are required in figure 2 for the demonstration of their release rates: referred to the respective activity in the liver, nearly 100 times more alanine aminotransferase and about 20 times more aspartate aminotransferase are released as compared with glutamate dehydrogenase.

Hitherto, the experimental results can be summarized as follows:

1. Hypoxia, anoxia and ischaemia lead to release of cellular enzymes.

2. The extent and the course of their elevation in the extracellular space depend on the concentration gradient, the intralobular distribution and the intracellular localization of the enzymes; moreover, they also depend on the extent and duration of lack of oxygen, the perfusion and the actual metabolic activity of the liver.

This last factor becomes particularly clear on figure 3 which shows the deleterious effects of higher temperature after hyperthermia on the leakage into the perfusion medium of a number of cellular enzymes: after the delayed increase of enzyme activities during the three hours at $20^{\circ} \mathrm{C}$, rewarming leads to a steep elevation, which totally cancels the economizing effects of hypothermia (2).

These experiments do not show whether the rise in temperature affects enzyme release only by widening the gap between energy requirement and oxygen supply, or whether the acceleration of diffusion and transport also leads to accelerated physical loss of enzymes. Investigations with isolated skeletal muscles have shown such a dependency of enzyme release on geometry and diffusion velocity (10). 

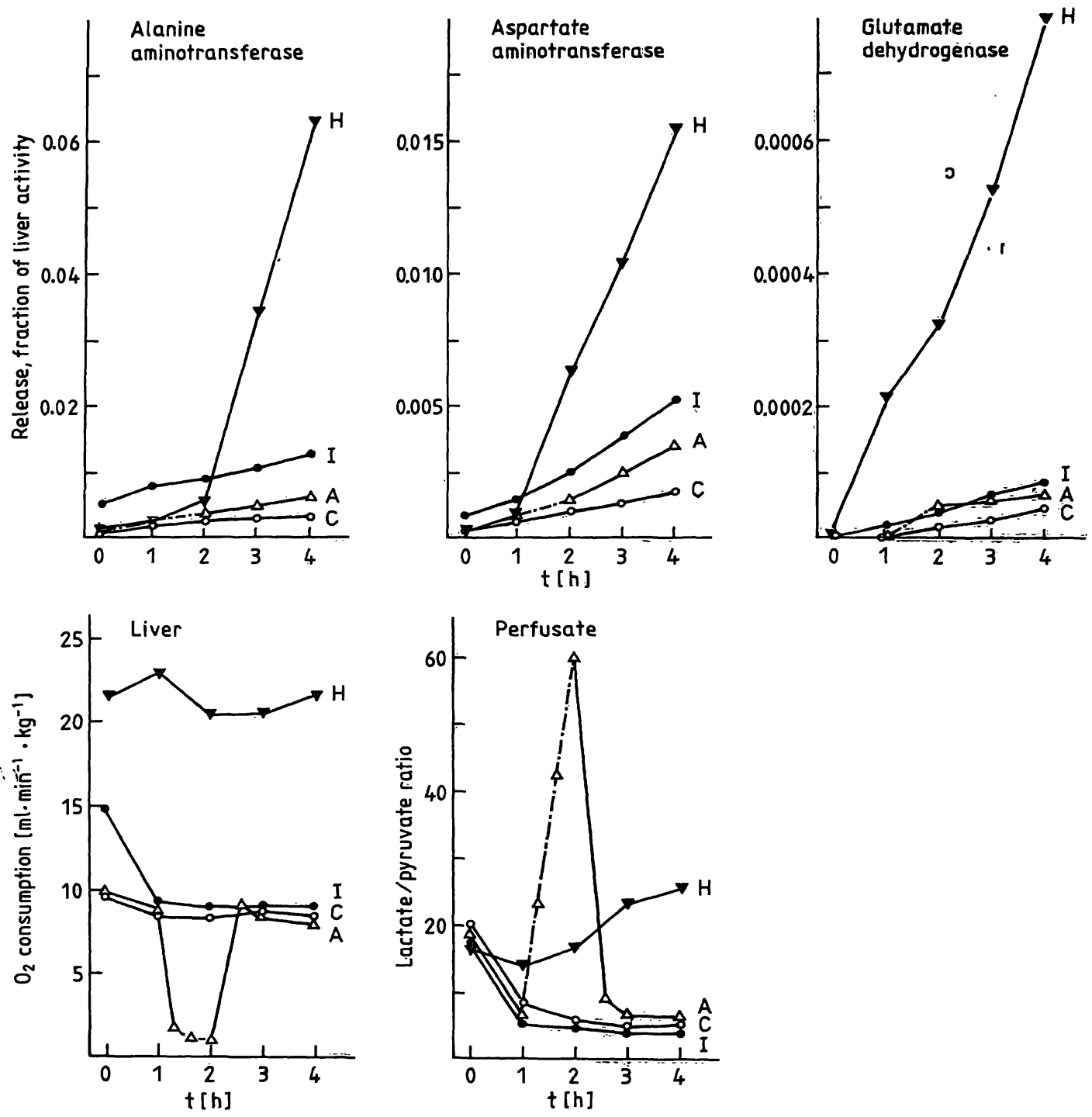

Fig. 2. Release of enzymes from the isolated haemoglobin-free perfused rat liver into the medium, given as fraction of their activity in the liver.

I: $\quad$ Ischaemia, 20 min before perfusion at $23^{\circ} \mathrm{C}$

$$
\mathrm{n}=4
$$

A: $\quad$ Anoxia, 1 hour after 1 hour normoxia; 2 hours reoxygenation at $23^{\circ} \mathrm{C}$ $\mathrm{n}=4$

$\mathrm{H}: \quad$ Hypoxia (relative) 4 hours perfusion at $37^{\circ} \mathrm{C}$

n $=2$

C: $\quad$ Control, 4 hours normoxic perfusion at $23^{\circ} \mathrm{C}$

$$
\mathrm{n}=10
$$

Bottom: $\mathrm{O}_{2}$ consumption of liver

Lactate/pyruvate quotient in the perfusate. Mean values;

from 1.c. (5), modified.

Another phenomenon, the so-called oxygen paradox, is barely recognizable from our own experiments. A significant elevation of release rates with re-oxygenation after anoxia was demonstrated only for aspartate aminotransferase. One reason for this may be that the constancy of flow masked the change from anoxia to normoxia in our procedure, as in studies with cultured cells, which led to similar results (11).

In experimental designs that produce hypoxia or anoxia by low-flow or no-flow, the enhancement of metabolism by the restoration of oxygen supply may ${ }^{\circ}$ be superimposed by the effect of wash-out phenomena $(12-15)$. The same is true with re-perfusion after ischaemia $(16-18)$, or when comparing enzyme leakage from exercising heart or skeletal muscle with that of a resting organ, or an organ kept at constant volume $(13,19,20)$.

Figure 4 from a paper of Lemasters et al. shows the oxygen paradox, exemplified by the loss of total protein and lactate dehydrogenase from the perfused liver, which occurs after the termination of the hypoxic low-flow period, and is dependent on its duration (15).

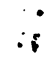

J. Clin. Chem. Clin. Biochem. / Vol. 25, 1987 / No. 9 

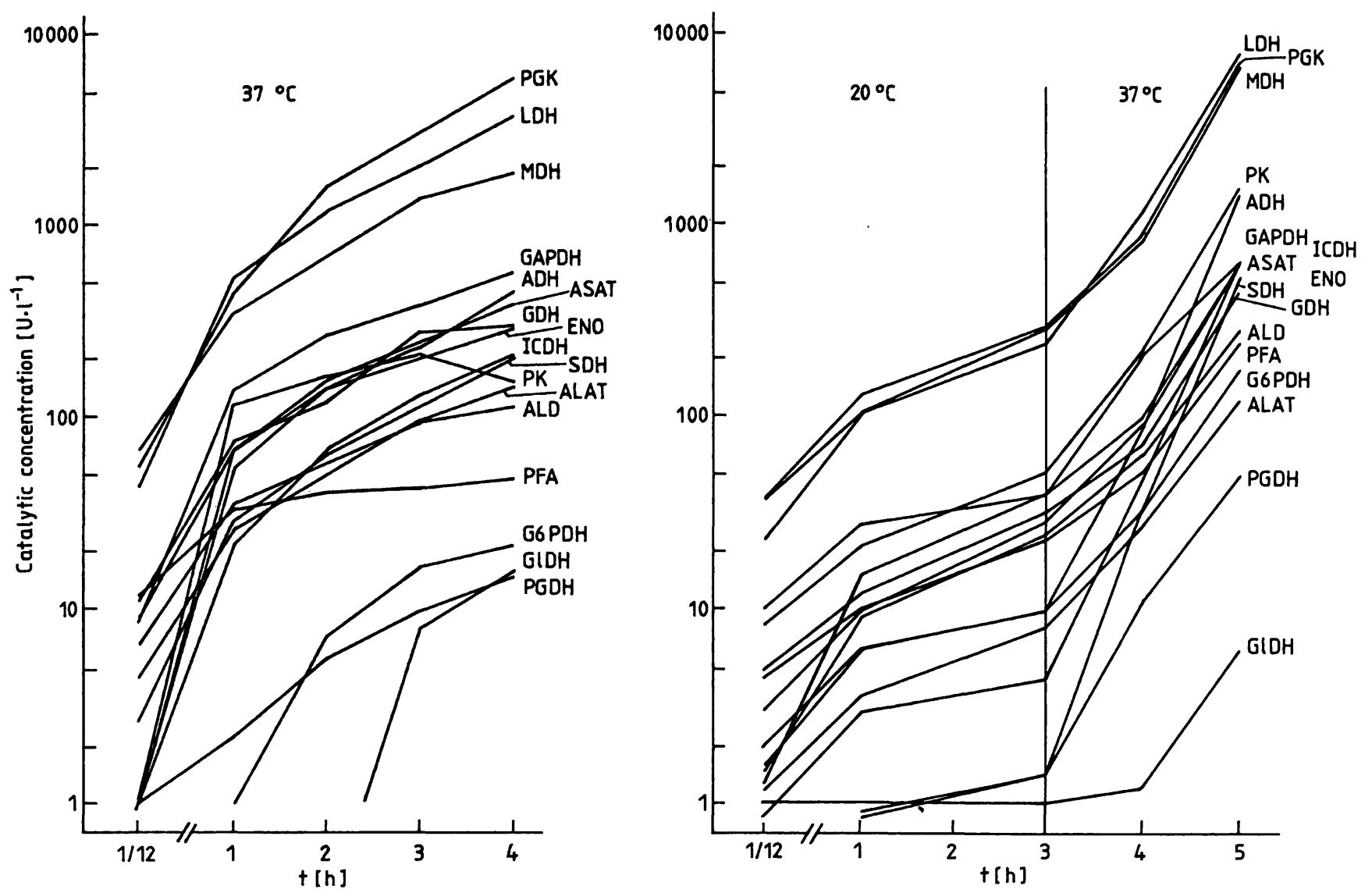

Fig. 3. Hb-free perfused rat liver; Release of enzymes into the perfusion medium during $4 \mathrm{~h}$ at $37^{\circ} \mathrm{C}$ and during $3 \mathrm{~h}$ at $20^{\circ} \mathrm{C}$ followed by $2 \mathrm{~h}$ at $37^{\circ} \mathrm{C}$.

Abbreviations used for enzymes see fig. 1, in addition:

PGK = phosphoglycerate kinase (EC 2.7.2.3);

$\mathrm{n}=3-17$; Mean values;

from 1.c. (2), modified.

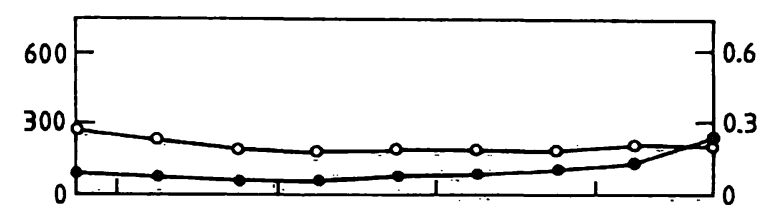

\section{Modification of substrate supply}

It is to be expected that lack of substrate, like lack of oxygen, also diminishes the energy-yield of cells and leads to increased membrane permeability.

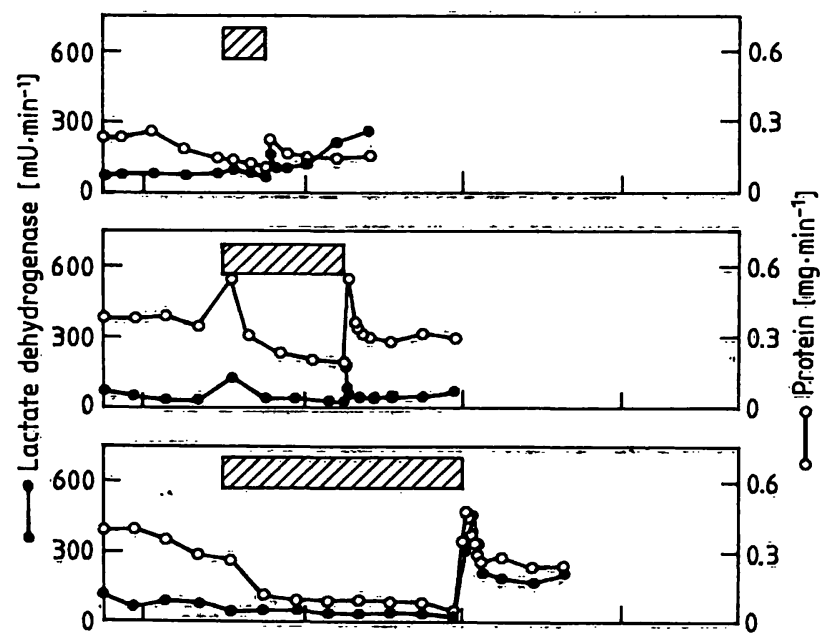

Figure 5 shows again the release rates of alanine aminotransferase, aspartate aminotransferase and glutamate dehydrogenase from the isolated, perfused rat liver. The reference data are the concentrations in the medium of glucose and pyruvate, the glycogen concentration in the liver before, and its decrease after, perfusion, and the ATP and ADP concentrations in the liver at the end of perfusion $(5,7)$. These parameters are compared under different conditions of endogenous and exogenous supply of substrates at $23^{\circ} \mathrm{C}$. The fed (F) animals correspond to the normoxic control group of the hypoxia experiments. $S$ denotes rats after 48 hours of fasting. In the FG and $S G$ groups glucose (otherwise $5.5 \mathrm{mmol} / \mathrm{l}$ ) was omitted from the perfusion medium.

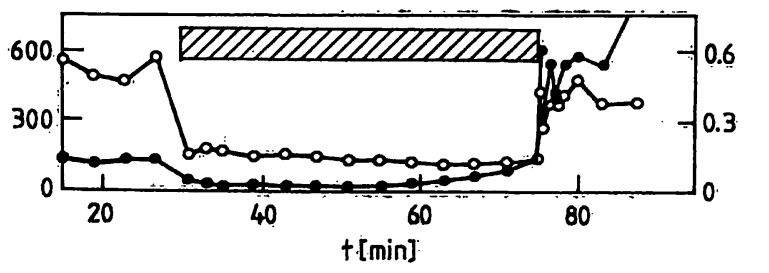

Fig. 4. Lactate dehydrogenase and protein release into the effluent perfusate after reoxygenation of hypoxic livers. Striped bars indicate periods of low flow; from I. c. (15), modified. 

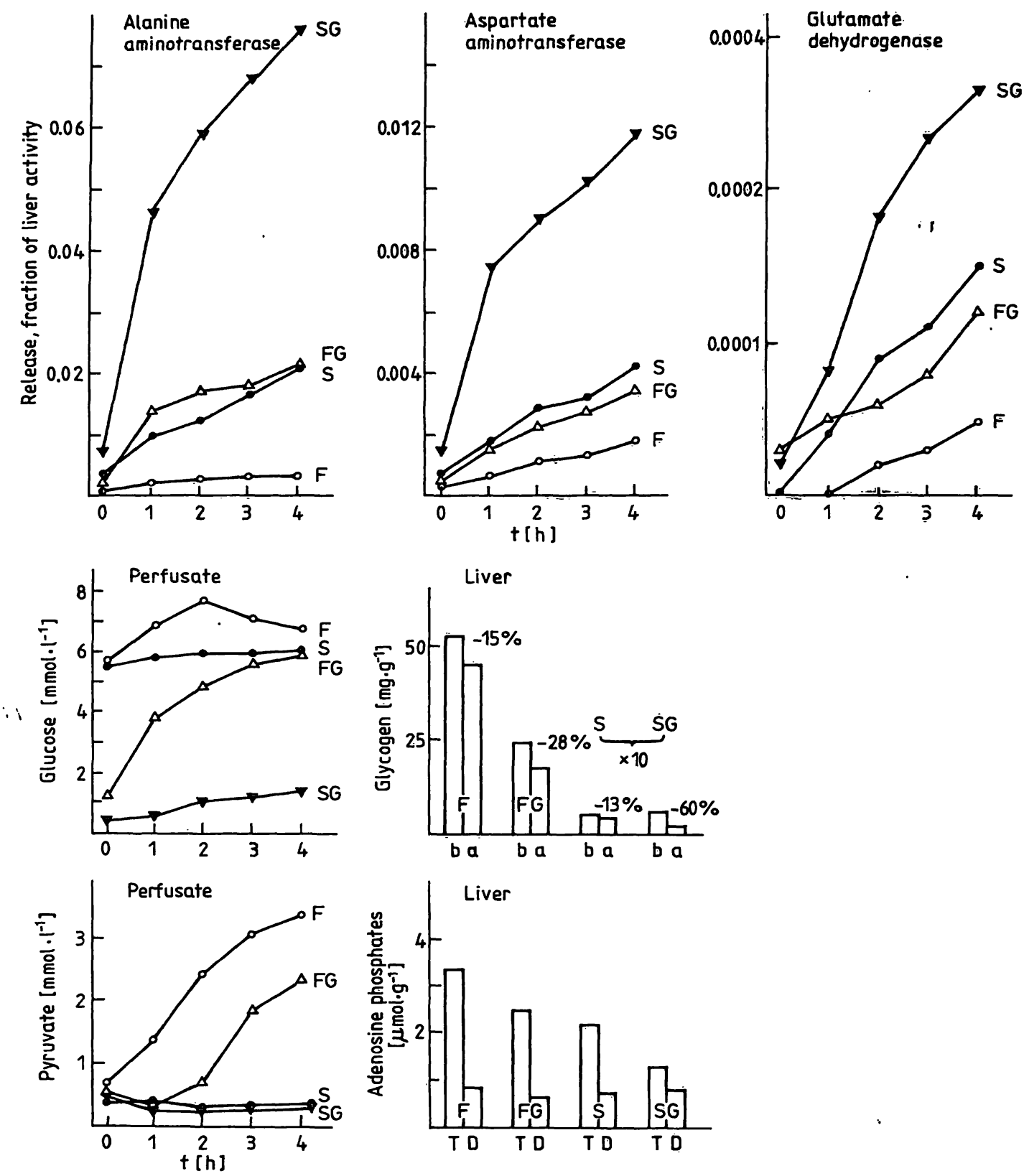

Fig. 5. Release of enzymes from the isolated, haemoglobin-free perfused rat liver into the medium, given as fraction of their activity in the liver.

F: $\quad$ Fed rats (controls), perfusion with $5 \mathrm{mmol} / \mathrm{l}$ glucose

FG: $\quad$ Fed rats - glucose free perfusion

S: $\quad$ Starved rats $(48 \mathrm{~h})$, perfusion with $5 \mathrm{mmol} / 1$ glucose

SG: $\quad \begin{array}{ll}n=6 \\ \text { Starved rats }- \text { glucose free perfusion }\end{array}$

$\mathrm{n}=3$

Bottom: Metabolite concentrations in the perfusate (left);

b: before perfusion

in the liver (right)

a: after perfusion

T: $\quad$ ATP after perfusion

D: ADP after perfusion

Mean values;

from 1.c. (5), modified.

The great significance of a sufficient supply of substrates for glycolysis is evident. When a liver has exhausted its glycogen stores and no exogenous glucose is available, the loss of alanine aminotransferase increases 20 -fold, and that of aspartate aminotrans- ferase and glutamate dehydrogenase 5-fold, compared with a well-nourished liver. The source of the substrates for glycolysis appears of no consequence; the increased release rates of the enzymes differ only insignificantly in response to. glycogen or glucose 
deprivation. The glucose-free perfused livers, however, consume more glycogen than the livers supplied with glucose. The former use their glycogen to build up a "normal" glucose level in the perfusion medium. As expected, livers of fasted animals with very low glycogen levels are unsuccessful in raising the glucose level of the perfusate.

The results of these and similar experiments indicate that enzyme release due to cellular injury, caused e.g. by hypoxia or by toxins, is modified by the nutritional state of the liver, particularly the availability of fuel for glycolysis, the nature of which is of no significance.

The relationship between the integrity of cells and their respective levels of glycogen and ATP has been well known for decades. This is also true with respect to organs other than liver $(21-23)$, which has been the subject of repeated studies. Figure 6 gives an example of such correlations between the release of malate dehydrogenase, the production of lactate and the ATP concentrations in cultured cardiomyocytes (24 a). In 1984, Piper et al., using their own different model system, reported results similar to those obtained with perfused liver. They also found no oxygen paradox, only one third of the previous enzyme leakage, when glucose was added to the medium, and less lactate production after 60 minutes of incubation.

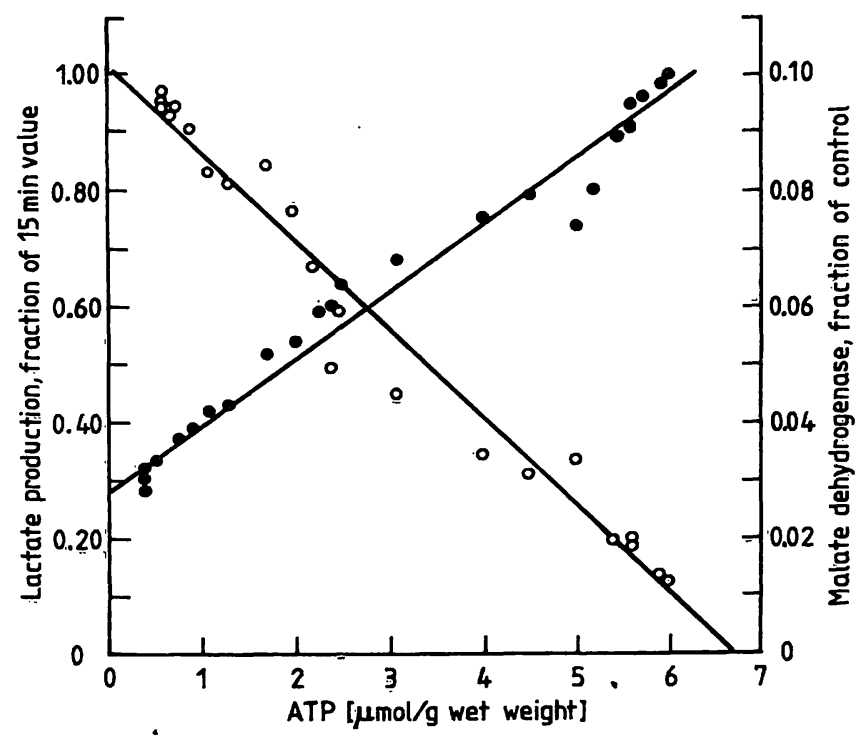

Fig. 6. Energy metabolism and enzyme release of cultured adult rat cardiocytes.

Correlation between lactate production rate (expressed as fraction of the $15 \mathrm{~min}$ value: $1.2 \mu \mathrm{mol} / \mathrm{g} \times \mathrm{min}$ ) and ATP content (full circles); $y=11.5 x+28.2 ; r=0.98$; $\mathrm{P}<0.001$.

Correlation between released malate dëhydrogenase açtivity (expressed as fraction of total cellular activity of control) and ATP content (open circles); $y=-1.5 x$ $+10.3 ; \mathrm{r}=-0.98 ; \mathrm{P}<0.0001$ (mean values, $\mathrm{n}=5$ ); from 1.c. (24b), modified.
They attribute the gradual impairment of glycolysis, which initially yielded $90 \%$ of total synthesized ATP, to several factors: inhibition of glyceraldehyde phosphate dehydrogenase, lack of co-substrate for the fructose-6-phosphokinase reaction, and imbalance of the ion composition. They conclude from the literature $(16,25,26)$, and from their own findings in the experiments with cardiomyocytes, that the cell damage is reversible above an ATP concentration of $2 \mu \mathrm{mol} / \mathrm{g}$, despite considerable enzyme losses, which depend on the intracellular localization of the respective enzymes and in general on the preceding or actual metabolic activity of the cells (11). These conclusions correspond to our former deductions from our findings in the perfused liver.

\section{Inhibition of metabolism}

Since the early investigations, individual inhibitors of metabolism with known site of impact have been used with the aim of localizing the state or process, which initiates the release of cellular enzymes, and to learn the sequence of events, including "the point of no return" with respect to cell damage $(2,3,22,27)$.

In figure 7, the effects of iodoacetate (IAA), which inhibits glycolysis, and of potassium cyanide $(\mathrm{KCN})$ which blocks cell respiration, on the isolated perfused rat liver are demonstrated, again exemplified by the release rates of the same three enzymes as in the former similar figures.

The reference data include lactate and pyruvate concentration in the medium and the distribution of the cytosolic and mitochondrial isoenzymes of aspartate aminotransferase and malate dehydrogenase, which link the two compartments via the aspartate malate shuttle, in the liver (28a).

Considering only the loss of enzymes, the toxic effect of iodoacetate is much more severe than the $\mathrm{KCN}$ induced liver damage. In the latter the activity of liver glycolytic enzymes increases by $80 \%$, and 10 times as much lactate is produced and released in the perfusion medium. By this enhancement of glycolysis the liver cells are evidently able to maintain a sufficiently high level of intermediates, and to adequately regulate metabolism, so that a marked increase in enzyme leakage is prevented. In contrast, when glycolysis is inhibited, the enzyme loss is so great that the concentration gradients between the cytosolic and the extracellular space fall below two.

Similar observations have been made by others. For example, some findings with the Langendorffperfused rat heart, as reported 1983 by Higgins \& 

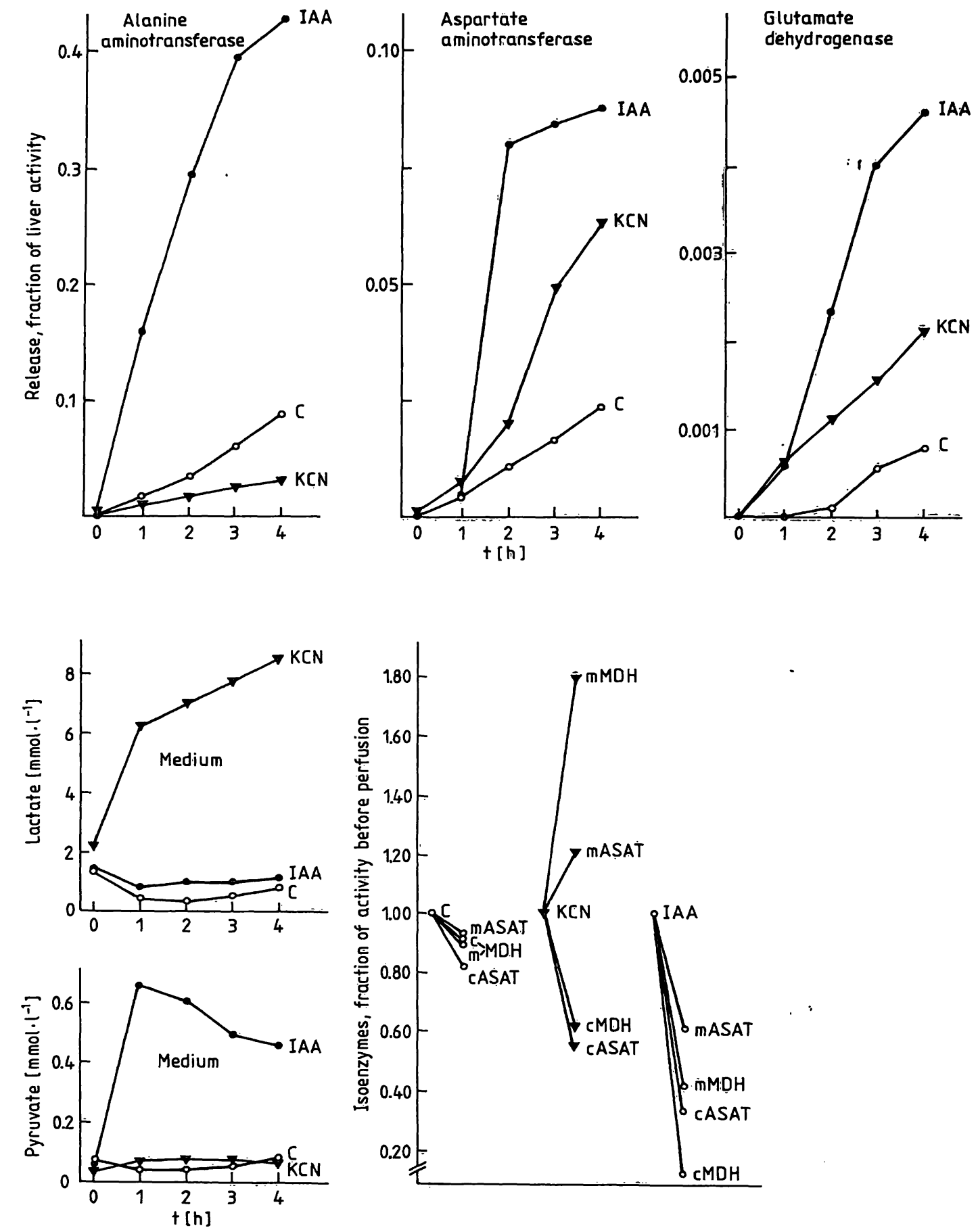

Fig. 7. Release of enzymes from the isolated, haemoglobin-free perfused rat liver into the medium, given as fraction of their activity in the liver (fasted rats, $37^{\circ} \mathrm{C}$; mean values)

C: Controls

$\begin{array}{ll} & \mathbf{n}=10 \\ \text { IAA: } & \text { Monoiodoacetate }\end{array}$

$-1 \mathrm{mmol} / \mathrm{l}$ perfusion medium

$$
\mathbf{n}=3
$$

KCN: Potassium cyanide

$-1 \mathrm{mmol} / \mathrm{l}$ perfusion medium

$$
\mathrm{n}=5
$$

Bottom: Metabolite concentrations in the perfusate

Isoenzymes in the liver after perfusion, given as fraction of activity in the liver before perfusion.

c -: $\quad$ cytosolic

m -: mitochondrial

ASAT $=$ aspartate aminotransferase

$\mathrm{MDH}=$ malate dehydrogenase. In vitro inhibition of aminotransferases is corrected by calculation;

from 1.c. (28 a), modified. 
Baylay (22) are shown in figure 8. During perfusion with a medium containing $0.2 \mathrm{mmol} / 1$ iodoacetate they observed a considerable release of lactate dehydrogenase as soon as lactate production ceased, while, with $1 \mathrm{mmol} / 1 \mathrm{KCN}$ in the perfusion medium, glycolysis was enhanced and the loss of lactate dehydrogenase was only slight. In both cases, the decrease of ATP was very similar. However, the concentration of total adenine nucleotides in the tissue fell by $50 \%$ in iodoacetate intoxication, while it remained constant during the application of $\mathrm{KCN}$.

It can be concluded from these and similar experiments that enhanced glycolysis yields sufficient energy, despite inhibited respiration or oxidative phosphorylation, to lessen or even prevent increased leakage of constitutive enzymes from liver or muscle cells. The reverse situation, i. e. inhibition of glycolysis with no inhibition of respiration, does not have the same effect.
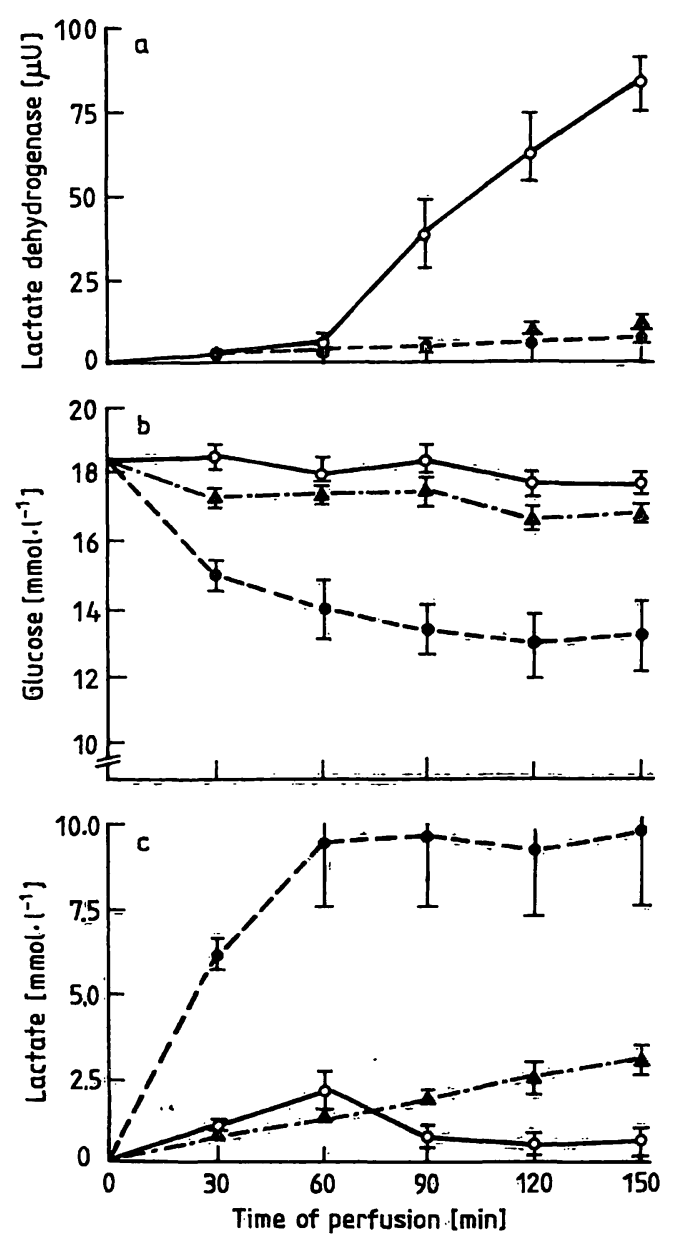

Fig. 8. Effect of $1 \mathrm{mmol} / \mathrm{l}$ cyanide ( $\bullet$ ), $0.1 \mathrm{mmol} / 1$ iodoacetate $(0)$ or no additions $(\Delta)$ on:

a) release of lactate dehydrogenase; b) perfusate glucose concentration; c) perfusate lactate concentration in isolated rat hearts during 150 min perfusion. Data are presented as mean $\pm S$. E. for four hearts; from 1. c. (22), modified.
These observations, which have been confirmed by other investigators, led to two hypotheses: firstly, that an adequate pool of adenine nucleotides, even exogenously substituted, enhances the integrity of cells and prolongs their survival in adverse conditions (25). Some doubt is cast on the causative role of total adenine nucleotide concentration in cell damage and preservation by the temporal sequence of the metabolic events (22).

The other concept states that glycolytically produced ATP, with or without actual compartmentation, would play a special role in the maintenance of the cytomembranes and the cytoskeleton $(22,23,28 \mathrm{~b})$.

\section{Modification of protein synthesis}

Besides the quantitative energy-related prerequisites of substrate supplementation, there are also qualitative aspects. Not only the amount, but also the composition of the nutrients affect enzyme release by modifying the susceptibility of cells via altered metabolic equilibria $(12,29)$. Clinical observations as well as experimental findings suggested that the direct effects of protein synthesis in the liver on the release of constitutive cell enzymes in acute injury should be studied after an enhancement of the former by a protein-rich diet. As noxious agent, galactosamine was chosen, because its effects are virtually not affected by induction of the biotransformation system (30).

The upper part of figure 9 shows the three exemplary enzymes in the plasma of rats, which received a nonlethal dose of galactosamine. The toxin was applied to the animals of the $\mathrm{P}$ group on the sixth day of an extremely protein-rich diet, and the animals of the $\mathrm{N}$ group were fed a balanced standard diet. Before the intoxication, the enzyme activities in plasma were identical in both collectives. After galactosamine, however, the peak values of alanine aminotransferase showed a 6-fold increase, those of aspartate aminotransferase increased nearly 4-fold, and those of glutamate dehydrogenase more than 8-fold in the plasma of the protein-rich fed rats, compared with the rats on the standard diet.

In the lower part of figure 9, the corresponding catalytic activities in the liver are shown. The increased enzyme synthesis is evident from the significantly higher catalytic concentrations of the aminotransferases before galactosamine, while, as expected, the effect on glutamate dehydrogenase is less dramatic. After the application of galactosamine, these different enzyme activities decreased by $40-50 \%$ in the livers 

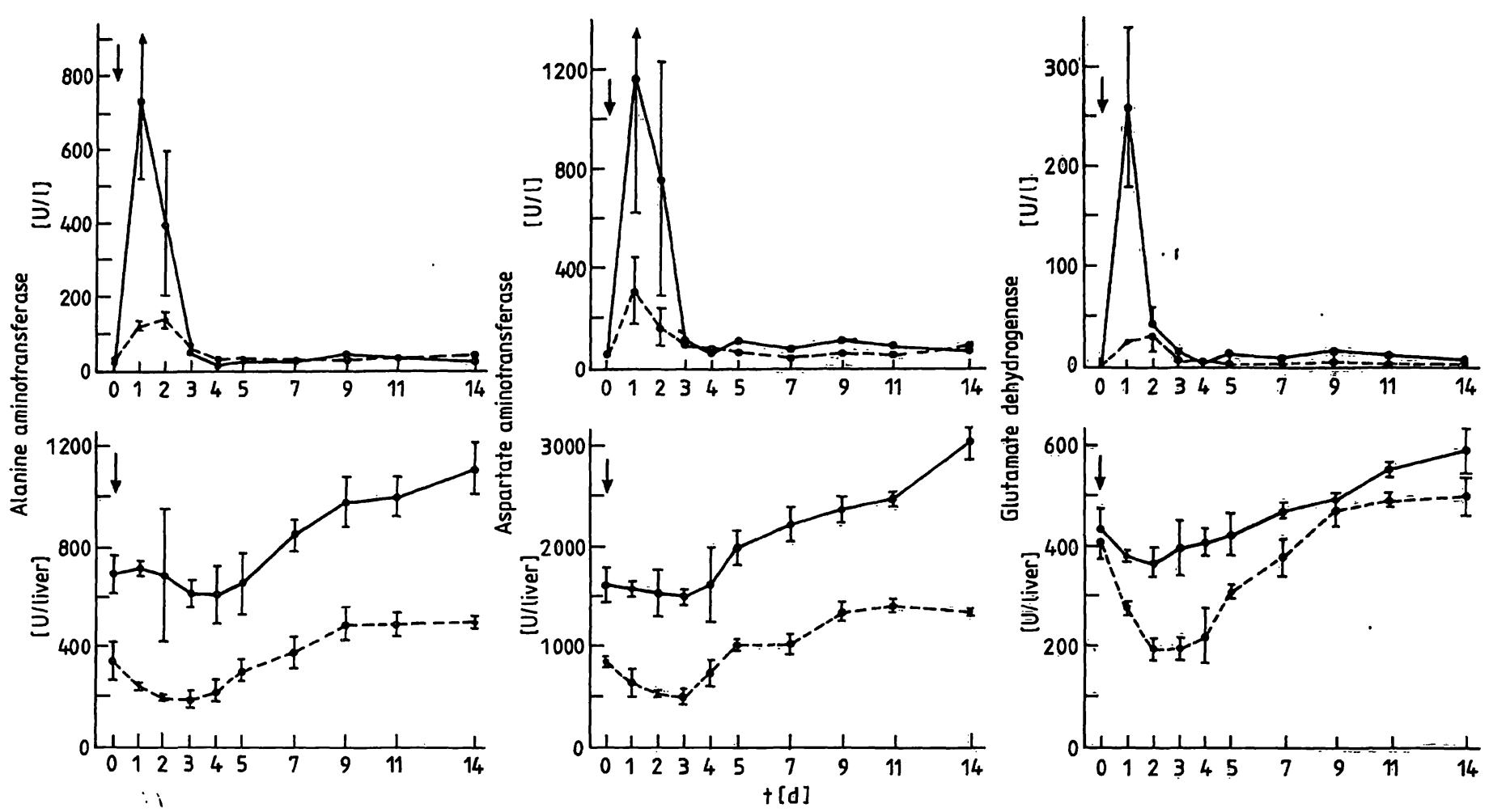

Fig. 9. Galactosamine-induced liver injury: Course of enzyme activities in plasma (top) and liverr (bottom) of rats ( \pm ( \pm SEM, $\mathrm{n}=30)$, fed a protein-rich $(92 \%$ protein, $0-0)$ or a standard diet $(20 \%$ protein, --0$)$

$\downarrow=0.4 \mathrm{~g}$ galactosamine $\mathrm{HCl}$ per $\mathrm{kg}$ body weight i. p.; from 1. c. (30), modified.

of the $\mathrm{N}$ rats, and by only $10-15 \%$ in the livers of the $\mathrm{P}$ animals. Moreover, in the latter group restoration of the tissue activity occurs in excess, as soon as the leakage into the extracellular space has ceased.

The question arises as to whether the higher concentration gradient alone accounts for the fact that the increase in the plasma is so much greater in the protein-rich nourished animals. Figure 10 shows the release rates of the enzymes for the two dietary groups. It is evident that the different concentration gradients do not suffice as an explanation. Even on the basis of the higher activities in liver tissue, the catalytic concentrations of the aminotransferases in $\mathrm{P}$ rats are nearly twice as high as those in the $\mathrm{N}$ rats, while glutamate dehydrogenase shows a 6-fold increase. The release rates are higher in themselves. Morphologically there is no indication of a less severe cell damage in the $P$ rats: the histology of the respective livers differed in small details, but there was no difference in the extent or duration of cellular injury (30).

The positive correlation between enżyme synthesis and enzyme levels in plasma for a particular cell injury may provide a basis for some observations in clinical hepatology, which are otherwise hard to explain, e.g. the pre-final fall of aminotransferases in plasma in fatal liver insufficiency, or the mitigated courses of enzymes in serum in immunocompromised or immunosuppressed patients, despite their progressive inflammatory liver diseases.

Others have established a positive correlation be: tween enzyme synthesis and enzyme release by the opposite approach, i.e. by the use of inhibitors of protein synthesis, such as cycloheximide $(12,31-33)$. Pappas (33), from his findings with acute carbon tetrachloride poisoning, comes to the rather far reaching conclusion that the leakage of cell enzymes could be as much an indication of cellular regeneration as a sign of cell damage. However, he does not discuss the problem of the suppression of the biotransformation of carbon tetrachloride by cycloheximide.

Nevertheless, as early as $1962, \mathrm{McLean}$ (34) reported that during refeeding of mal- and undernourished Jamaican children with a high-protein diet, sudden transient elevations of alanine aminotransferase and isocitrate dehydrogenase occurred in plasma with no indication of liver disorders or the slightest disturbance of the children's well-being. Thereupon, he formed the hypothesis that in the course of a precipitated reparation of enzyme losses with plenty of substrate supply, de=novo-synthesis of enzymés may 


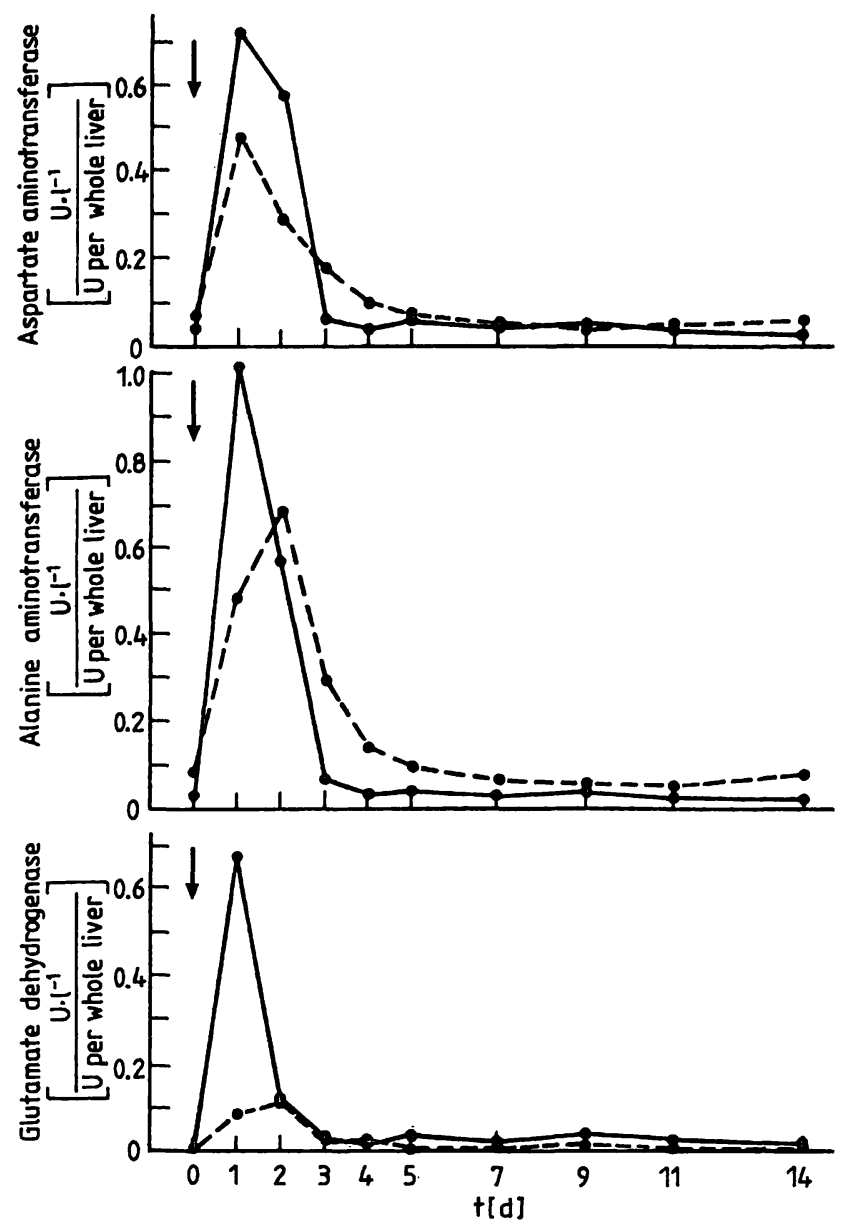

Fig. 10. Galactosamine-induced liver injury: Course of the release rates of enzymes of rats, fed a protein-rich or a standard diet.

For explanations see fig. 9;

from 1.c. (30), modified.

exceed the production of stabilizing cellular structures, so that the new constitutive enzymes would be lost instead of being transferred to and fixed at their respective sites of action.

Experimental confirmation of this possibility is, however, lacking. Rather, there are contradictory findings, e.g. the proof that in cultured hepatocytes in the presence of galactosamine newly synthesized lactate dehydrogenase does not leak into the surrounding medium without having mixed with the previously existing pool of lactate dehydrogenase (35). However, in these experiments, enzyme synthesis was inhibited, not enhanced. Moreover, lactate dehydrogenase, a cytosolic protein, which bears no signal peptide and does not require much vectorial processing, may not be representative of other enzymes, which are synthesized by free ribosomes, but transported to other compartments for metabolic action. The import into mitochondria, e. g., through the inner membrane, depends on the ATP concentration in the mitochondrial matrix and can be prevented by inhibition of respiration or oxidative phosphorylation (36).
Nevertheless, whether enzymes are produced by processing of precursor peptides or not, the molecules found in the plasma correspond to the mature "working" form or an even later molecular modification $(37,38)$.

\section{Modification of membrane structure}

The still widespread conviction that cellular enzymes in the plasma originate from cell necrosis is sustained by the difficulty in imaging how these macromolecules apparently transgress the cell membrane as easily or even more easily than much smaller molecules, a phenomenon, on which the diagnostic sensitivity of enzyme determination in serum is based.

Wilbrandt published 1941 one of the oldest reflections on the subject. He considered the colloid-osmotic swelling with stretched and finally torn membranes, due to the failure of ion pumps, to be the main reason for a passively increased cell permeability (39).

In the fifties Zierler explained the enzyme efflux from the working or injured muscle by the enhancement or the disorder of the continuous oscillations of the plasma membranes, which leads to the irregular occurrence of more or less wide gaps (40). Neither hypothesis is disproved, and they even seem more probable in the light of recent studies on pathological pores in plasma membranes, e.g. those caused by bacterial exotoxins. However, both theories assign to the damaged plasma membrane the properties of a molecular sieve, and this is not in agreement with all findings in the various pathological conditions.

In the early seventies, the development of electron microscopy and an increased understanding of the structure of cytomembranes and the cytoskeleton gave rise to another proposed mechanism, i.e. disorders of the membrane by cross linking, detachment or depolymerisation of the cytoskeletal actin filaments. This was first described on isolated hepatocytes in phalloidin poisoning (41), and later recognized as a fairly common and non-specific phenomenon $(15,42-46)$. It is illustrated in figure 11: in addition to a normal hepatocyte covered evenly with small microvilli, the figure shows a cell damaged by ethanol, and another injured by phalloidin, both of which show severe alterations of their plasma membranes (46).

Destruction and cross-linking of actin filaments both labilize the plasma membrane, which forms protrusions in isolated cells, according to the pressure gradient. These so-called blebs can separate from the cell. 

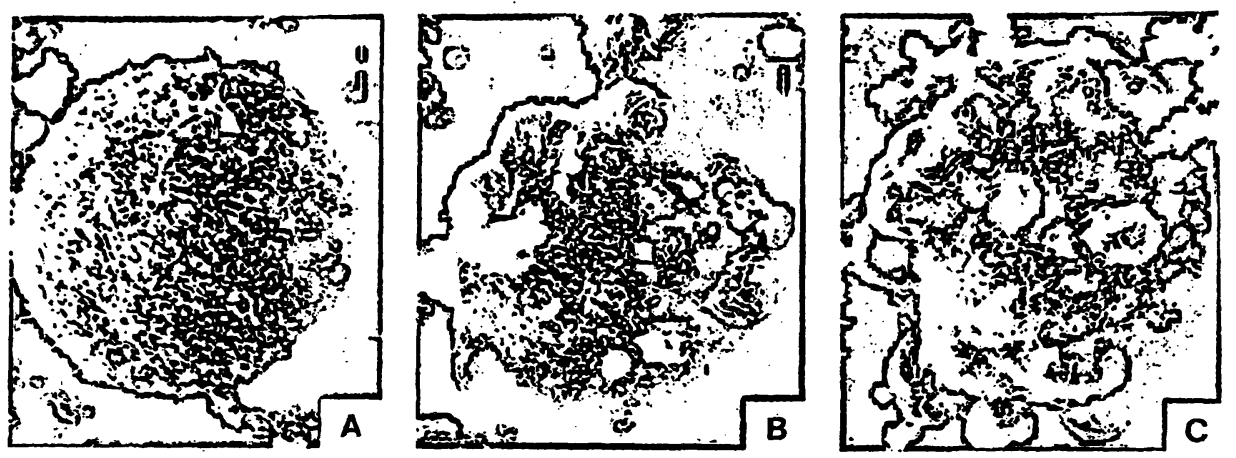

Fig. 11. Scanning electron micrographs of isolated hepatocytes.

A: Typical hepatocyte from control rat showing abundant microvilli uniformly covering the cell surface.

B: Hepatocyte from ethanol-fed rat showing the appearance of blebs on the cell surface with a diminished number of microvilli.

C: Blebbing of the plasma membrane in hepatocyte treated with phalloidin.

(A) $\times 3000$; (B) $\times 2800$; (C) $\times 2950$.

from l.c. (46).

In whole tissue they are represented by membrane pits and vesicles, which can also be shed or emptied into the extracellular space (38). "Blebbing", "vesicle shedding", "apoptosis" and "zeiosis" are often used synonymously, but it is not always certain that they describe the same thing. Marked differences exist e. g. in the size of the vesicles. Moreover, some authors never find mitochondria within the blebs $(47,48)$. Thus, these investigators consider blebbing to be the reason for the lack of negative correlation between the molecular mass of the enzymes and their release rates in all pathological conditions $(3,49,50)$, and for the low release rates of the mitochondrial enzymes and isoenzymes compared with those of cytosolic enzymes $(48,49)$.

Others, however, have demonstrated the occurrence of mitochondria in the blebs (11). The composition of the protrusions differs also in other respects: in part they appear to consist virtually of membrane fragments with the respective membrane-bound enzymes $(42,51)$, in part they contain cytosolic enzymes enveloped by one of the two lipid-layers of the plasma membrane (52), and finally no plasma membranelike envelope for the various mostly cytosolic enzymes can be detected (15).

There are areas of agreement, e. g. on the reversibility of vesiculation - at least up to a certain size of the vesicles - analogous to the reversibility of general cell swelling. It follows that the enzymes, which are thereby released, come from living and, as a rule, surviving cells.

Some authors even consider blebbing to be a protective mechanism, which prolongs or guarantees the survival of the cells. The local extrusion of cellular material diminishes the pressure within the cells and the cellular volume, and by sacrificing a portion, the whole is saved $(47,53)$.

Figure 12 shows experiments with rat skeletal muscle, which make it plausible that the release of cytosolic enzymes, e.g. lactate dehydrogenase starts immediately when, by blebbing, the volume of the cells swollen in hypotonic medium is suddenly reduced. This is, of course, a regulated process, depending on ATP from oxidative phosphorylation, which rather contradicts the special role which has been assigned to glycolytically produced ATP. Namely, when 2,4dinitrophenol is added, the swelling increases steadily, but the enzyme leakage is only one half (47)).

The temperature-dependence of the contraction-mediated or at least contraction-associated enzyme losses from heart and skeletal muscles, which are caused by anoxia, 2,4-dinitrophenol or caffeine during calcium-free perfusion, or by the calcium paradox, can be attributed to differences in metabolic activity as well as to differences in the velocity of inand efflux of ions, which alter the properties of the membranes $(19,41,51,54,55)$. Both causes are interrelated by direct effects of calcium.

\section{Role of calcium homoeostasis}

$\mathrm{Ca}^{2+}$ ions bind to anionic groups of phospholipids and glycolipids in the membranes and thereby reduce membrane fluidity. Table 3 shows that addition of calcium to calcium-free incubated hepatocyte plasma membranes increases the fractions of free fatty acids and lysolecithin, but diminishes that of phosphatidylethanolamine (56). The kinetics and character of the 

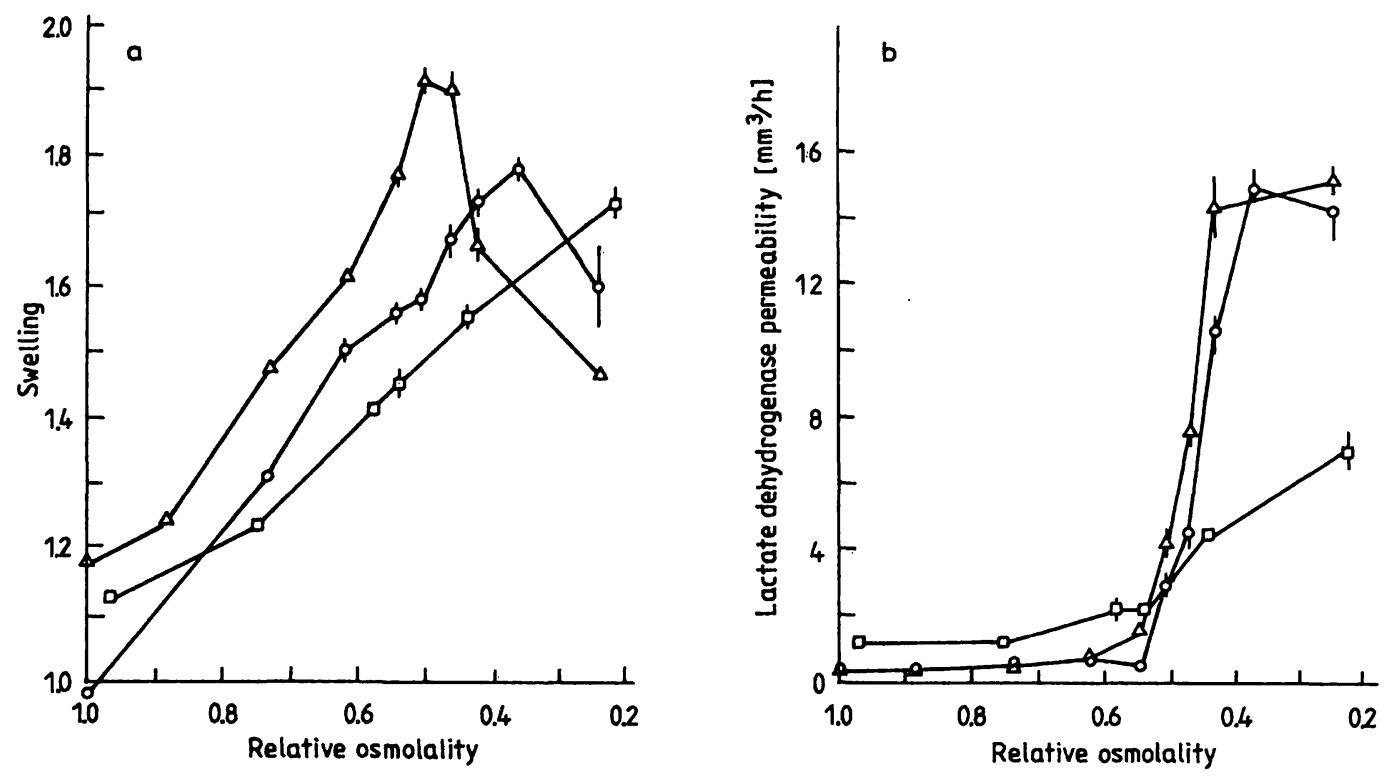

Fig. 12a. Swelling of skeletal muscle under nonpoisoned conditions in media of decreasing relative osmolality. Muscles were incubated nonisometrically in hypotonic Krebs-Ringer buffers $(\Delta)$, isometrically in hypotonic Krebs-Ringer buffers (O), and isometrically in hypotonic sodium pyrophosphate buffers ( $\square$ ).

b. Lactate dehydrogenase permeability of skeletal muscle under nonpoisoned conditions in media of decreasing relative osmolality. Muscles were incubated nonisometrically in hypotonic Krebs-Ringer buffers $(\Delta)$, isometrically in hypotonic Krebs-Ringer buffers (0), and isometrically in hypotonic sodium pyrophosphate buffers ( $\square$ ). The permeabilities were calculated for an incubation interval of $60 \mathrm{~min}$ between the 30th and 90th min.

After 30 min of preincubation, the medium was replaced by fresh buffer of identical composition;

from 1.c. (47), modified.

Tab. 3. Lipid composition following incubation of hepatocyte membranes in the presence or absence of calcium.

\begin{tabular}{|c|c|c|c|}
\hline \multirow[t]{2}{*}{ Constituent } & \multicolumn{2}{|c|}{$\begin{array}{l}\text { Percent of total lipid } \\
\text { weight } \\
\text { (mean } \pm \text { SEM) }\end{array}$} & \multirow[t]{2}{*}{$\mathrm{p}$} \\
\hline & no $\mathrm{Ca}^{2+}$ & $\begin{array}{l}4 \mathrm{mmol} / \mathrm{l} \\
\mathrm{Ca}^{2+}\end{array}$ & \\
\hline Cholesterol & $21.2 \pm 1.8$ & $19.6 \pm 1.6$ & ns \\
\hline Cholesterol esters & $17.8 \pm 2.1$ & $14.9 \pm 1.3$ & ns \\
\hline Triglycerides & $3.0 \pm 0.4$ & $2.7 \pm 0.4$ & ns \\
\hline Fatty acids & $6.0 \pm 0.4$ & $9.9 \pm 0.4$ & $<0.001$ \\
\hline Lecithin & $20.9 \pm 3.1$ & $21.9 \pm 0.6$ & ns \\
\hline Lysolecithin & $3.4 \pm 1.0$ & $8.3 \pm 1.1$ & $<0.01$ \\
\hline Sphingomyelin & $14.2 \pm 1.3$ & $12.4 \pm 1.3$ & ns \\
\hline $\begin{array}{l}\text { Phosphatidyletha- } \\
\text { nolamine }\end{array}$ & $13.6 \pm 1.0$ & $10.4 \pm 0.8$ & $<0.01$ \\
\hline
\end{tabular}

from 1.c. (56), modified

changes, however, also indicate indirect effects of calcium through activation of the membrane-bound phospholipases. The formation of more lysolecithin would result rather in enhanced than impaired membrane fluidity.

Probably, it is the alternation of rigid and labilized parts of the membrane, which leads to local weakening of the structures. Together with the effect on the cytoskeleton, partly cross-linkage, partly depolymerization, the end result is the blebbing process (15, 47).
Figure 13 shows that modifications of the intracellular concentration of $\mathrm{Ca}^{2+}$ are not mandatory. Infusion of low dose of phospholipase $\mathrm{C}(0.1 \mathrm{U} / \mathrm{l})$ provokes abrupt leakage of creatine kinase from the isolated septum of rabbit heart without increase in calcium or barium uptake (57). The 40 -fold dose of phospholipase $C$, however, leads to a massive release of constitutive enzymes, and probably to irreversible necrosis.

Since Judah and his co-workers (1956) published their findings on the accumulation of calcium in damaged liver cells, shown on figure 14 (58), it has been generally understood that impaired intracellular calcium homoeostasis plays a role in the loss of enzymes from the cells. Whether it is generally the cause of increased enzyme leakage, or just an early event, concomitant with the release of cytosolic enzymes $(48,59-61)$, or whether calcium accumulation is the ultimate common result of all types of cell injury, are matters of controversy. Evidently, the answer depends on the species and age, of the organ studied, on the type and severity of the cell damage and on the enzymes in question $(57,59,62)$.

For a long time, most investigators favoured the last explanation. Thus, 20 years ago we too designed a rather primitive graph (fig. 15) of the sequence of events thought to be related to enzyme release during 

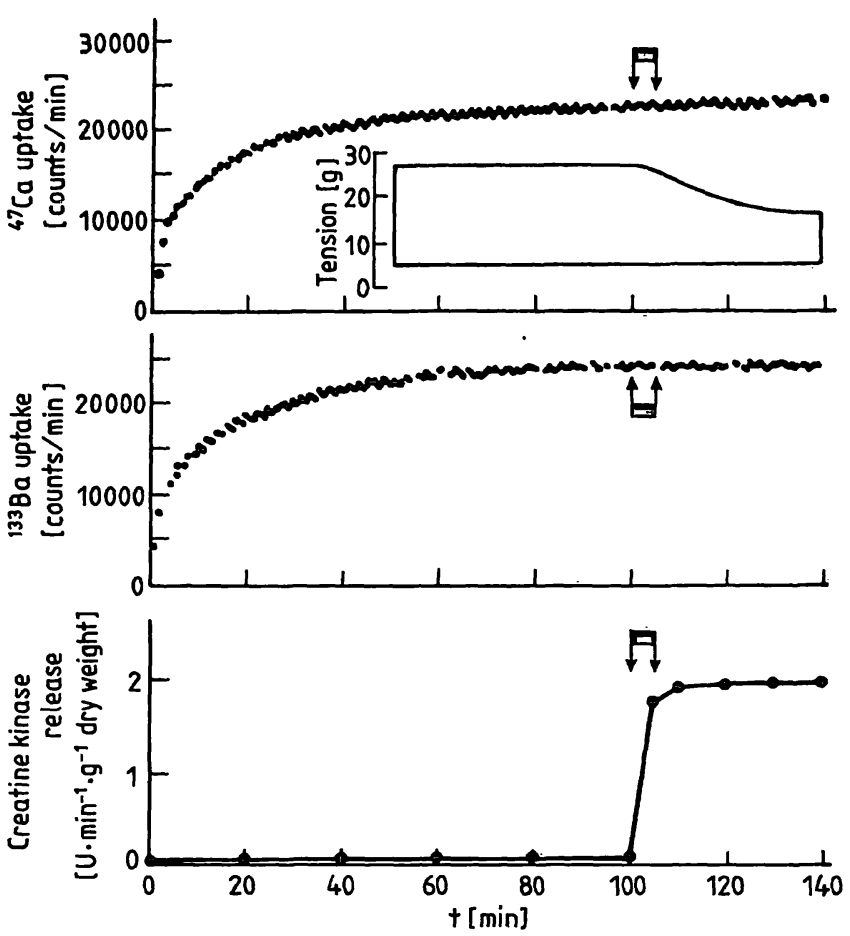

Fig. 13. Effect of phospholipase C (100 U/l) infusion $(\downarrow \downarrow)$ on tissue ${ }^{47} \mathrm{Ca}^{2+}$ uptake (upper panel), tissue ${ }^{133} \mathrm{Ba}^{2+}$ uptake (middle panel), and the rate of creatine kinase release (lower panel) in the adult rabbit heart septum; from 1. c. (57), modified.

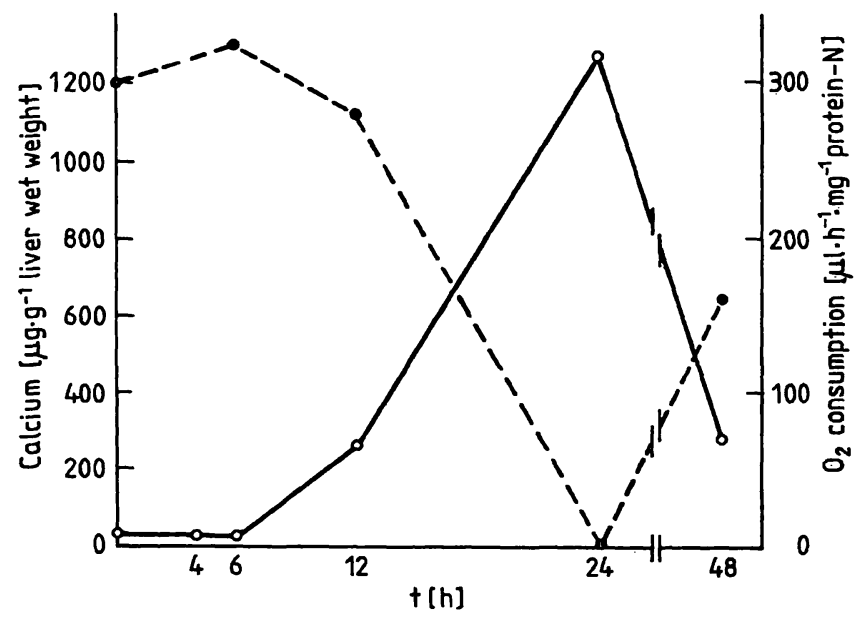

Fig. 14. Intracellular calcium accumulation $(0-0)$ and oxygen consumption $(\bullet--,-)$ of rat liver in acute thioacetamide intoxication; from 1.c. (58), modified.

cellular injury, which attempts to summarize the results of several groups working in the fifties and sixties $(26,58,63)$.

Recently more evidence has appeared in favour of the importance of early calcium effects, particularly in muscle cells.

A primary direct causative role may be ascribed to calcium imbalance only under the extremely artificial conditions that provoke the calcium paradox. However, it appeared sensible to update the old scheme in figure 15. This has been done in figure 16, which ${ }^{\circ}$

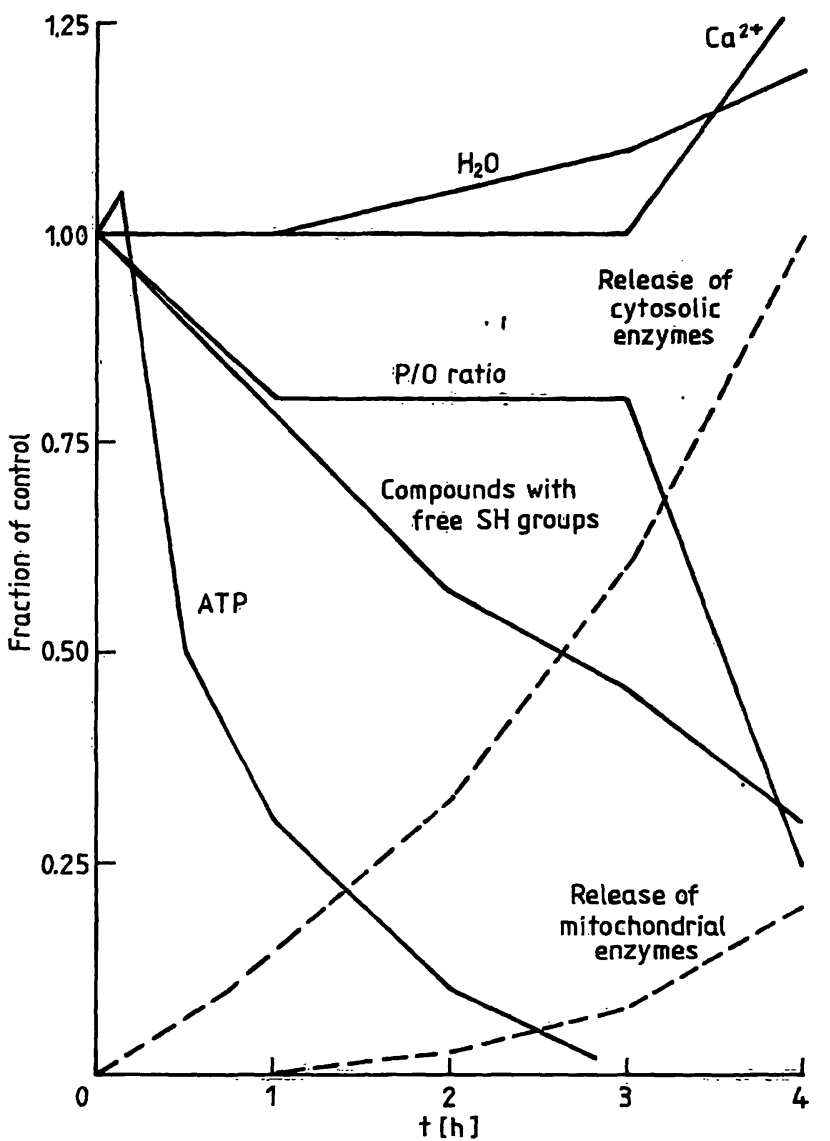

Fig. 15. Hypothetical scheme of the course of cell damage in relation to enzyme release I; from 1.c. (26), modified.

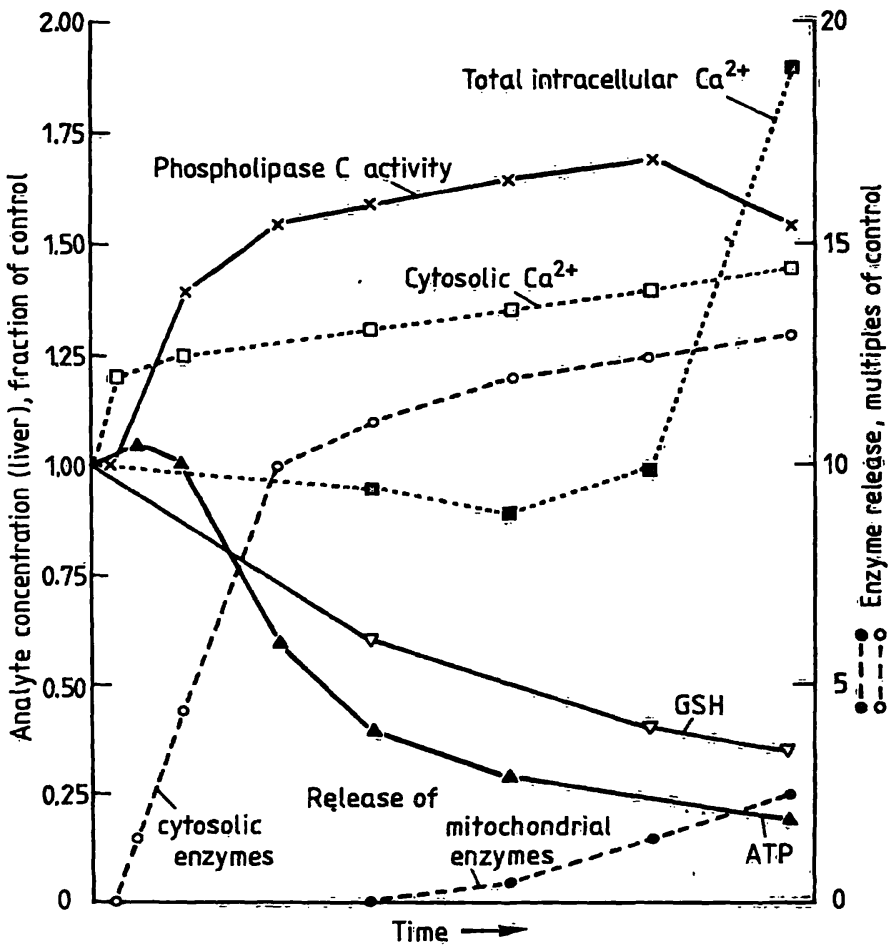

Fig. 16. Hypothetical scheme of the course of cell damage in relation to enzyme release II.

is likewise grossly simplified, but illustrates an attempt to reconcile contradictory findings and points of view by taking into consideration the compartmentation of the intracellular calcium, and by distinguish- 
ing a compensated and a decompensated disturbance of the calcium equilibrium in the cytosol. Cytosolic calcium homeostasis is regulated by the mitochondria in dependence on NADPH, and by the endoplasmic reticulum in dependence on GSH. Between 0.1 and $0.5 \mu \mathrm{mol} / 1$, cytosolic calcium is controlled by the plasma membrane permeability barrier against the steep concentration gradient from the extracellular space.

Minor increases in membrane permeability, e.g. by direct effects of bacterial exotoxins or phalloidin, or by efflux of calcium from the cisternae of the endoplasmic reticulum, e. g. due to lack of GSH after its consumption for the detoxification of reactive metabolites (60), lead to slight but fast elevations of cytosolic $\mathrm{Ca}^{2+}$, which are sufficient to exert signal effects like the activation of phospholipases and proteases or structural modifications of the cytoskeleton
$(15,47,53,54)$. These intensify or even initiate the membrane disorders, and cytosolic enzymes are lost by leakage. This process is reversible (56), either by blebbing, or by restoration of homoeostasis in the presence of cytosolic ATP by means of the ion pumps, or by the much more "risky" process of augmented sequestration of non-ionized calcium in the mitochondria. The latter process utilizes ATP and is saturable, and its failure and exhaustion indicates the point of no return. While mitochondrial enzymes begin to leak out, the cell dies - full of calcium.

The scheme in figure 16 is not comprehensive. Numerous important, possibly decisive points are missing and those indicated are in part purely hypothetical. In view of the sometimes confusing clinical observations, much remains to be learned about enzyme release.

\section{References}

1a. Schmidt, E., Schmidt, F. W. \& Wildhirt, E. (1958) Klin. Wochenschr. 36, 280-287.

1b. Bücher, Th., Schmidt, E. \& Schmidt, F. W. (1959) Transact. 9th Middle East Med. Ass. 85-101.

2. Herfarth, C., Schmidt, E. \& Schmidt, F. W. (1969) Bruns' Beitr. Klin. Chir. 217, 363 - 373, 454-462, 463-471.

3. Schmidt, E. \& Schmidt, F. W. (1967) Nature (London) 213, 1125-1126.

4. Schmidt, E., Schmidt, F. W. \& Herfarth, C. (1966) Enzymol. Biol. Clin. 7, 53-72, 167-184, 185-202.

5. Schmidt, E., Schmidt, F. W., Möhr, J., Otto, P., Vido, I., Wrogemann, K. \& Herfarth, C. (1975) Liver morphology and enzyme release. Further studies in the isolated perfused rat liver. In: Pathogenesis and mechanisms of liver cell necrosis (Keppler, D., ed.) MTP Press Ltd. Lancaster, pp. $147-162$.

6. Lindena, J., Diedrichs, F., Wittenberg, H. \& Trautschold, I. (1986) J. Clin. Chem. Clin. Biochem. 24, 61-71.

7. Schmidt, E. \& Schmidt, F. W. (1976) FEBS Letters 62 , (Suppl.) E 62-E 79.

8. Schimassek, H. (1962) Life Sc̃i. $11,629-634$

9. Kessler, M. \& Schubotz, R. (1986) Die $\mathrm{O}_{2}$-Versorgung der hämoglobin-frei perfundierten Rattenleber. In: Stoffwechsel der isoliert perfundierten Leber (Staib, W., Scholż, R., eds.) Springer, Heidelbërg, pp. 12-20.

10. Suarez-Kurtz, G. \& Eastwood, A. B. (1981) Am. J. Physiol. 241 (Cell Physiol. 10) C98 = C105.

11. Piper, H. M., Schwartz, P., Hütter, J. F. \& Spiekermann, P. G. (1984) J. Mol. Cell Cardiol. 16, 995-1007.

12. Bradford, B. U., Marotto, M., Lemasters, J. J. \& Thurman, R. G. (1986) J. Pharmacol. Exper. Ther. 236, 263-268.

13. Humphrey, S. M., Thomson, R. W. \& Gavin, J. B. (1984) J. Mol. Cell Cardiol. 16, 915-930.

14. Laarse, A., van der, Dijkman, P. R. M., van, Altona, J. C.. Zoet, A. C. M. \& Oemrawsingh, P. V. (1984) Cardiovasc. Res. $18,438-442$.

15. Lemasters, J. J., Stemkowski, C. J., Ji, S. \& Thurman, R. G. (1983) J. Cell Biol. 97, 778-786.

16. Brömme, H. J., Kässner, G., Richter, F. \& Dargel, R. (1982) Acta Biol. Med. Germ. 41, 979 989.

17. Ong, L., Reiser, P., Coromilas, J., Scherr, L. \& Morrison. J. (1983) New Engl. J. Med. 309, 1-6.

18. Panteghini, M., Cuccia, C. \& Calarco, M. 81987) Adv. Clin. Enzymol. 5, 87-93.

19. Ganote, C. E. \& Sims, M. A. (1984) Amer. J. Pathol. 116, 94-106.

20. Lindena, J., Küpper, W. \& Trautschold, I. (1986) J. Clin. Chem. Clin. Biochem. 24, 19-33.

21. Bricknell, O. L. \& Opie, L. H. (1978) Circ. Res. 43, 102105.

22. Higgins, T. J. C. \& Bailey, P. J. (1983) Biochim. Biophys. Acta 762, 67-75.

23. Macleod, D. R. \& Daniel, E. E. (1965) J. Gen. Physiol. 48, 887-899.

24a. Piper, H. M., Schwatz, P., Spahr, R., Hütter, J. F. \& Spiekermann, P. G. (1984) J. Mol. Cell Cardiol. 16, 385388.

24b.Piper, H. M., Hütter, J. F. \& Spieckermann, P. G. (1984) Life Sci. 35, 127-134.

25. Cole, A. W. G. \& Palmer, T. N. (1979) Clin. Chim. Acta 92, 93-100.

26. Schmidt, E. (1968) Enzym-Austritt. In: Praktische Enzymologie (Schmidt, F. W., ed.) Huber - Bern, pp. 93-144.

27. Jones, D. A., Jackson, M. J. \& Edwards, R. H. T. (1983) Clin. Sci. 65, 193-201.

28a. Schmidt, E. (1968) Austritt von Zell-Enzymen aus der isolierten, perfundierten Rattenleber. In: Stoffwechsel der isoliert perfundierten Leber (Staib, W. \& Scholz, R., eds.) Springer - Heidelberg, pp. 53-62.

28b. Anderson, G. L. \& Morris, R. G. (1987) Life Sci. 23, $23-$ 32.

29. Mudd, R. C., Grahn, M. F. \& Davies, I. J. (1981) Biochem. Soc. Transactions 9, 561-562.

30. Schmidt, E., Schmidt, F. W., Feldmann, U., Ranft, U., Holz-Slomczyk, M., Kubale, R., Ohlendorf, S., Raupach, R. \& Rüther, G. (1979) Clin. Enzym. Symp. 2, 37-54.

31. Bossmann, B. \& Haschen, R. J. (1984) J. Clin. Chem. Clin. Biochem. 22, 449-451.

32. Kaplan, M. M. \& Righetti, A. (1970) J. Clin. Invest. 49, $508-516$.

33. Pappas, jr., N. J. (1986) Clin. Chim. Acta 154, 181-190.

34. MéLean, A. E. M. (1962) Lancet $i i, 1294-1295$.

35. Eisenmann, A., Phillips, J. E., Schulze-Specking, A. \& Decker, K. (1984) Hoppe-Seyler's Z. Physiol. Chem. 365, 427-436. 
36. Nelson, N., Maccecchini, M. L., Rudin, Y. \& Schatz, G. (1979) Import of proteins into mitochondria. In: Biological functions of proteinases. (Holzer, H. \& Tschesche, H., eds.) Springer - Berlin - Heidelberg - New York, pp. 109-119.

37. Tsuda, M., Taketani, S., Sawamura, T., Shiozaki, Y., Tokunaga, R. \& Sameshima, Y. (1985) J. Biochem. 97, 1391 1399.

38. Welbourne, T. C., Phifer, T., Thomas, M. \& Dass, P. D. (1983) Life Sci. 33, $1141-1147$.

39. Wilbrandt, W. (1941) Pflügers Archiv Ges. Physiol. 245, $22-52$.

40. Zierler, K. L. (1958) Ann. N. Y. Acad. Sci. 75, 227-234.

41. Weiss, E., Sterz, I., Frimmer, M. \& Kroker, R. (1973) Beitr. Pathol. 150 345-356.

42. De Broe, M. E., Borgers, M. \& Wieme, R. J. (1975) Clin. Chim. Acta 59, 369-372.

43. Prentki, M., Chaponnier, C., Jeanrenaud, B. \& Gabbiani, G. (1979) J. Cell Biol. 81, 592-607.

44. Trump, B. F., Penttila, A. \& Berezesky, I. K. (1979) Virchow's Arch. B., Cell Pathol. 29, 281-296.

45. Trump, B. F., Penttila, A. \& Berezesky, I. K. (1979) Virchow's Arch. B, Cell Pathol. 29, 297-307.

46. Yamada, S., Mak, K. M. \& Lieber, C. S. (1985) Gastroenterology 88, 1799-1806.

47. Diederichs, F., Mühlhaus, K., Trautschold, I. \& Friedel, R. (1979) Enzyme 24, 404-415.

48. Fredericks, W. M., Myagkaya, Gl. L., Bosch, K. S., Fronik, G. M., Veen, H. v., Vogels, I. M. C. \& James, J. (1983) Histochemistry 78, 459-472.

49. Friedel, R., Diederichs, F. \& Lindena, J. (1979) Adv. Clin. Enzymol. 1, 70-105.
50. Kopprasch, S., Orlik, H. \& Scheuch, D. W. (1985) Enzyme $34,122-128$.

51. Takahashi, K., Kobayashi, T., Yamada, A., Tanaka, Y.; Inoue, K. \& Nojima, S. (1983) J. Biochem. 93, 1691-1699.

52. Ott, P., Hope, M. J., Verkleij, A. J., Roelofsen, B., Brodbeck, U. \& Deenen, L. L. M., van (1981) Biochim. Biophys. Acta $641,79-87$.

53. Diederichs, F., Mühlhaus, K., Wittenberg, H. \& Trautschold, I. (1986) J. Clin. Chem. Clin. Biochem. 24, 3-9.

54. Ganote, C. E., Liu, S. Y., Safavi, S. \& Kailtenbach, J. P. (1981) J. Mol. Cell Cardiology 13, 93-106.

55. Hearse, D. J., Humphrey, S. M. \& Bullock, G. R. 81978.) J. Mol. Cell Cardiol. 10, 641-668.

56. Livingstone, C. J. \& Schachter, D. (1980) Biochemistry 19, $4823-4827$.

57. Nakanishi, T., Young, H. H., Shimizu, T., Nishioka, K. \& Jarmakani, J. M. (1984) J. Mol. Cell Cardiol. 16, 519532.

58. Gallagher, C. H., Gupta, D. N., Judah, J. D. \& Rees, K. R. (1956) J. Pathol. Bact. 72, 193-201.

59. Fortier, P. A., Bedford, G. K. \& Chiong, M. A. (1984) Can. J. Physiol. Pharmacol. 62, 1158-1165.

60. Jewell, S. A., Bellomo, G., Thor, H., Orrenius, S. \& Smith, M. T. (1982) Science 217, 1257-1258.

61. Rabkin, S. W. (1986) Can. J. Physiol. Pharmacol. 64, 602608.

62. Schanne, F. A. X., Kane, A. B., Young, E. E. \& Farber, J. L. (1979) Science 206, 206-208.

63. Dawkins, M. J. R., Judah, J. C. \& Rees, K. R. (1959) J. Pathol. Bact. 77, 257-275.

Frau Prof. Dr. Ellen Schmidt Medizinische Hochschule Hannover Konstanty-Gutschow-Straße 8 D-3000 Hannover 61 